\title{
Intracellular pH during "Chemical Hypoxia” in Cultured Rat Hepatocytes Protection by Intracellular Acidosis against the Onset of Cell Death
}

\author{
Gregory J. Gores, Anna-Liisa Nieminen, Barnaby E. Wray, Brian Herman, and John J. Lemasters \\ Laboratories for Cell Biology, Department of Cell Biology \& Anatomy, School of Medicine, University of North Carolina \\ at Chapel Hill, Chapel Hill, North Carolina 27599
}

\begin{abstract}
The relationships between extracellular $\mathrm{pH}\left(\mathrm{pH}_{\mathrm{o}}\right)$, intracellular $\mathbf{p H}\left(\mathrm{pH}_{\mathrm{i}}\right)$, and loss of cell viability were evaluated in cultured rat hepatocytes after ATP depletion by metabolic inhibition with $\mathrm{KCN}$ and iodoacetate (chemical hypoxia). $\mathrm{pH}_{\mathbf{i}}$ was measured in single cells by ratio imaging of $2^{\prime}, 7^{\prime}$-biscarboxyethyl-5,6-carboxyfluorescein (BCECF) fluorescence using multiparameter digitized video microscopy. During chemical hypoxia at $\mathrm{pH}_{\mathrm{o}}$ of $7.4, \mathrm{pH}_{\mathrm{i}}$ decreased from 7.36 to 6.33 within 10 min. $\mathrm{pH}_{\mathrm{i}}$ remained at 6.1-6.5 for 30-40 min (plateau phase). Thereafter, $\mathrm{pH}_{\mathrm{i}}$ began to rise and cell death ensued within minutes, as evidenced by nuclear staining with propidium iodide and coincident leakage of BCECF from the cytoplasm. An acidic $\mathrm{pH}_{\mathbf{0}}$ produced a slightly greater drop in $\mathbf{p H}_{\mathrm{i}}$, prolonged the plateau phase of intracellular acidosis, and delayed the onset of cell death. Inhibition of $\mathrm{Na}^{+} / \mathrm{H}^{+}$exchange also prolonged the plateau phase and delayed cell death. In contrast, monensin or substitution of gluconate for $\mathrm{Cl}^{-}$in buffer containing $\mathrm{HCO}_{3}^{-}$abolished the $\mathrm{pH}$ gradient across the plasma membrane and shortened cell survival. The results indicate that intracellular acidosis after ATP depletion delays the onset of cell death, whereas reduction of the degree of acidosis accelerates cell killing. We conclude that intracellular acidosis protects against hepatocellular death from ATP depletion, a phenomenon that may represent a protective adaptation against hypoxic and ischemic stress.
\end{abstract}

\section{Introduction}

Both hypoxia and a decrease in $\mathrm{pH}$ occur during ischemic tissue injury. The effects of hypoxia and the resulting decrease in ATP have drawn considerable attention, but fundamental information is lacking concerning the role of extracellular $\mathrm{pH}$ $\left(\mathrm{pH}_{\mathrm{o}}\right)^{1}$ and intracellular $\mathrm{pH}\left(\mathrm{pH}_{\mathrm{i}}\right)$ in hypoxic cellular damage.

Preliminary reports of portions of this work were presented at the 38th Annual Meeting of the American Association for the Study of Liver Diseases, Chicago, IL, 27-28 October 1987 (42).

Address reprint requests to Dr. John J. Lemasters, Laboratories for Cell Biology, Department of Cell Biology \& Anatomy, School of Medicine, University of North Carolina at Chapel Hill, Campus Box 7090, 108 Swing Building, Chapel Hill, NC 27599-7090.

Received for publication 10 May 1988 and in revised form $16 \mathrm{Au}$ gust 1988.

1. Abbreviations used in this paper: BCECF, 2',7'-biscarboxyethyl-5,6carboxyfluorescein; BCECF-AM, acetoxymethyl ester of BCECF; DIDS, 4,4'-diisothiocyano-2,2'-stilbene disulfonate; IAA, iodoacetic

J. Clin. Invest.

(C) The American Society for Clinical Investigation, Inc.

$0021-9738 / 89 / 02 / 0386 / 11 \quad \$ 2.00$

Volume 83, February 1989, 386-396
In particular, the relationships between $\mathrm{pH}_{\mathrm{i}}$ and the morphologic and functional abnormalities observed during ischemic and hypoxic cellular injury are unclear. In excitable tissue like myocardium, mild tissue acidosis may be protective early and injurious late during hypoxic or ischemic stress (1-3). The early protective effect of acidosis in myocytes is reported to be due to inhibition of ATP hydrolysis via the oligomycin-sensitive ATPase, thereby preventing ATP depletion (4). However, once ATP is depleted, a synergism between tissue acidosis and ATP depletion in promoting cell injury during hypoxia has been suggested (3). In such nonexcitable cells as hepatocytes, Erlich ascites tumor cells, and renal proximal tubule cells, a protective effect of mild extracellular acidosis has also been found during hypoxic stress $(5,6)$.

Recently, we observed a similiar protective effect of extracellular acidosis in hepatocytes depleted of ATP with KCN plus iodoacetic acid (IAA) (chemical hypoxia) (7). Cell killing was also delayed by inhibition of $\mathrm{Na}^{+} / \mathrm{H}^{+}$exchange. By contrast, monensin, a $\mathrm{Na}^{+} / \mathrm{H}^{+}$ionophore, potentiated cell killing, as did exchange of intracellular $\mathrm{Cl}^{-}$for extracellular $\mathrm{HCO}_{3}^{-}$. These findings suggest that cytoplasmic acidosis protects against hypoxic cell death. Earlier attempts to measure $\mathrm{pH}_{\mathrm{i}}$ in suspensions of isolated hepatocytes indicated little or no decrease in $\mathrm{pH}_{\mathrm{i}}$ after 30 or $45 \mathrm{~min}$ of anoxia $(6,8)$, but the temporal relationship between $\mathrm{pH}_{\mathrm{i}}, \mathrm{pH}_{\mathrm{o}}$, and the onset of irreversible cell injury remains incompletely defined.

With the advent of quantitative digitized video microscopy (9), it is now possible to make serial measurements of $\mathrm{pH}_{\mathrm{i}}$ in single living cells (10). Using multiparameter techniques (11), $\mathrm{pH}_{\mathrm{i}}$ can be directly compared with cell morphology and viability. The objective of this study thus was to determine the relationship between $\mathrm{pH}_{\mathrm{o}}, \mathrm{pH}_{\mathrm{i}}$, and loss of viability in cultured rat hepatocytes during ATP depletion. The results indicate that intracellular acidosis develops rapidly in hepatocytes during ATP depletion. This acidic $\mathrm{pH}_{\mathrm{i}}$ persists for many minutes but begins to rise shortly before the onset of cell death. We conclude that intracellular acidosis delays the onset of cell death after ATP depletion, a phenomenon that may protect against ischemic damage to tissue.

\section{Methods}

Hepatocyte isolation and culture. Hepatocytes were isolated by collagenase perfusion of livers from male Sprague-Dawley rats (200-300 g) as described previously (12) and resuspended in culture medium at 450,000 cells $/ \mathrm{ml}$. $1-\mathrm{ml}$ aliquots were cultured in $35 \times 10 \mathrm{~mm}$ Petri dishes (Becton-Dickinson \& Co., Oxnard, CA) on 22-mm square glass

acid; KRH, Krebs-Ringers Hepes buffer; KRHB, Krebs-Ringers Hepes bicarbonate buffer; MES, 2-( $N$-morpholino)-ethanesulfonic acid; MOPS, 3-( $N$-morpholino)-propanesulfonic acid; MDVM, multiparameter digitized video microscopy; $\mathrm{pH}_{\mathrm{i}}$, intracellular $\mathrm{pH} ; \mathrm{pH}_{\mathrm{o}}$, extracellular $\mathrm{pH}$. 
coverslips. Before culturing, coverslips were sterilized $20 \mathrm{~min}$ in $95 \%$ alcohol, air dried, coated with acid-soluble type I collagen from rat tail tendon ( $20 \mu \mathrm{g} /$ coverslip) (13), and air dried again. The culture medium was Waymouth's MB-752/1 containing $26.7 \mathrm{mM} \mathrm{NaHCO}, 2 \mathrm{mM}$ L-glutamine, 5\% FCS, and $100 \mathrm{nM}$ insulin. Hepatocytes were used after $16-36 \mathrm{~h}$ of culture in $5 \% \mathrm{CO}_{2} /$ air at $37^{\circ} \mathrm{C}$.

Solutions. The basic incubation buffer was Krebs-Ringers-Hepes buffer (KRH) containing $115 \mathrm{mM} \mathrm{NaCl}, 5 \mathrm{mM} \mathrm{KCl}, 1 \mathrm{mM} \mathrm{KH}_{2} \mathrm{PO}_{4}$, $2 \mathrm{mM} \mathrm{CaCl}_{2}, 1.2 \mathrm{mM} \mathrm{MgSO}_{4}$, and $25 \mathrm{mM} \mathrm{Na}$-Hepes buffer, $\mathrm{pH}$ 7.4. Solutions were air saturated. Assuming a partial pressure for carbon dioxide of 0.3 Torr, $\mathrm{HCO}_{3}^{-}$ion content was $0.2 \mathrm{mM}$ in nominally bicarbonate-free buffers at $\mathrm{pH}$ 7.4. In some experiments, $15 \mathrm{mM}$ $\mathrm{NaHCO}_{3}$ was added and Hepes concentration was reduced to $10 \mathrm{mM}$ (Krebs-Ringers Hepes bicarbonate buffer [KRHB]). For those experiments in which $\mathrm{pH}$ was $<6.8$, Hepes $\left(\mathrm{pK}_{\mathrm{a}} 7.31\right)$ was replaced with 2-( $N$-morpholino)-ethanesulfonic acid (MES) $\left(\mathrm{pK}_{\mathrm{a}} 5.96\right)$ (14). In other experiments, $\mathrm{Na}^{+}$ion was replaced with choline or $\mathrm{Cl}^{-}$ion was replaced with gluconate. Aerobic $\mathrm{Na}^{+}$and $\mathrm{Cl}^{-}$free media were not toxic compared with KRH. Neutralized KCN was prepared in a fume hood by addition of $100 \mu$ l of concentrated $\mathrm{HCl}$ to $1.15 \mathrm{ml}$ of $1.087 \mathrm{M} \mathrm{KCN}$ to yield a $1 \mathrm{M}$ stock solution. $0.2 \mathrm{M}$ IAA was dissolved in buffer and neutralized with $\mathrm{NaOH}$. $1 \mathrm{mM}$ 2',7'-biscarboxyethyl-5,6-carboxyfluorescein acetoxylmethyl ester (BCECF-AM) was dissolved in DMSO. $0.5 \mathrm{mM}$ rhodamine 123 and $1 \mathrm{mM}$ propidium iodide were dissolved in deionized, distilled water. $20 \mathrm{mg} / \mathrm{ml}$ rhodamine-dextran was freshly dissolved in sterile phosphate-buffered saline.

Fluorometry. Fluorescence measurements of BCECF released from freshly isolated hepatocyte suspensions were made with a fluorescence spectrophotometer (model 850-40; Perkin-Elmer Corp., Norwalk, CT) using excitation and emission wavelengths of 440 and $530 \mathrm{~nm}$ (5- and 10-nm slits), respectively. A standard curve was obtained using BCECF-free acid in KRH buffer.

Multiparameter digitized video microscopy (MDVM). Experiments measuring $\mathrm{pH}_{\mathrm{i}}$ were performed using an MDVM system described previously $(9,11)$. The microscope was an inverted fluorescence microscope (IM-35; Carl Zeiss, Inc., Thornwood, NY). Excitation light was provided by a $100-\mathrm{W}$ mercury vapor lamp and passed through an interference and neutral density filter wheel assembly to select wavelength and intensity under computer control. A low-light, intensified silicon-intensified target (ISIT) video camera (model 66; MTI-Dage, Michigan City, IN) collected fluorescent images that were fed to a computer (MicroPDP 11/23; Digital Equipment Corp., Maynard, MA) and digitized with a QVG/AFA-123 video acquisition and display board set (Datacube, Inc., Peabody, MA) for frame averaging, background subtraction, ratioing and storage on 8-in. floppy disks. Experiments were also routinely recorded with a half-inch time-lapse video cassette recorder (model TC3900; RCA, Lancaster, PA).

BCECF-loaded cells were excited at wavelengths of $440 \mathrm{~nm}(\mathrm{pH}$ insensitive) and $490 \mathrm{~nm}$ ( $\mathrm{pH}$ sensitive). Fluorescence was imaged through a 510-nm dichroic reflector and 515-565 interference filter. Fluorescence of rhodamine 123-loaded cells was imaged using a 450-490-nm excitation filter, a 510-nm dichroic reflector, and a 515-565 interference filter. Fluorescence of propidium iodide, rhodamine-dextran, and $0.1-\mu \mathrm{m}$ rhodamine-labeled latex microspheres was imaged using a 546-nm excitation filter, a 580-nm dichroic reflector, and a 590-nm-long pass filter.

Dye loading. BCECF was loaded by incubating hepatocytes in culture medium with $5 \mu \mathrm{M}$ BCECF-AM for $30 \mathrm{~min}$ at $37^{\circ} \mathrm{C}$. Endogenous esterases hydrolyzed BCECF-AM to trap free BCECF in the cytosol as a membrane-impermeant tetracarboxylic acid (15). After loading, the cells were washed three times with buffer and mounted on the microscope. Over the period of study, little or no loss of BCECF occurred until close to the onset of cell death.

Rhodamine 123 identified intact, polarized mitochondria (11). Cultured hepatocytes were loaded with BCECF as described above and incubated with $\mathrm{Ca}^{2+}$-free $\mathrm{KRH}$ containing $5 \mathrm{mM}$ succinate and $20-100 \mu \mathrm{M}$ digitonin. $800 \mathrm{nM}$ rhodamine 123 was added subsequently to identify intact mitochondria. The $\mathrm{Ca}^{2+}$-free, succinate-containing medium prevented mitochondrial depolarization after addition of digitonin.

To label lysosomes, rats were injected with $20 \mathrm{mg} / 100 \mathrm{~g}$ body weight rhodamine-dextran i.p. $16 \mathrm{~h}$ before isolation of hepatocytes. As described previously for injected fluorescein-dextran, rhodamine-dextran is taken up by endocytosis to become concentrated in secondary lysosomes as a nondegradable marker $(16,17)$.

To label the early diffuse endocytic, prelysosomal compartment, cultured hepatocytes were incubated with rhodamine-labeled microspheres for $30 \mathrm{~min}$ at $37^{\circ} \mathrm{C}$ in culture media. In preliminary experiments, microspheres were noted to be taken up by hepatocytes. After 1-2 h of incubation, microsphere fluorescence became punctate, consistent with uptake by endocytosis and subsequent translocation into lysosomes. After loading, the cells were washed three times with buffer and mounted on the microscope.

Measurement of $\mathrm{pH}_{i}$ and determination of cell death. $\mathrm{pH}_{\mathrm{i}}$ was measured by ratio imaging of BCECF fluorescence excited at 440 and 490 $\mathrm{nm}$. After background subtraction, the image at $440 \mathrm{~nm}$ was divided by the image at $490 \mathrm{~nm}$ on a pixel-by-pixel basis. In situ calibration curves between pH 5.5 and 7.5 were generated in BCECF-loaded hepatocytes by addition of $10 \mu \mathrm{M}$ nigericin, $\mathrm{a} \mathrm{K} / \mathrm{H}^{+}$ionophore, in 115 $\mathrm{mM} \mathrm{K}^{+}$buffer to equalize $\mathrm{pH}_{\mathrm{i}}$ and $\mathrm{pH}_{\mathrm{o}}$ (18). Identical standard curves were obtained by using monensin, a $\mathrm{Na}^{+} / \mathrm{H}^{+}$ionophore, in $10 \mathrm{mM}$ $\mathrm{Na}^{+}$buffer where the remainder of the $\mathrm{Na}^{+}$was replaced isosmotically with choline. Data were displayed as two-dimensional color maps or averaged for all pixel elements within a single cell.

Cultured hepatocytes were equilibrated with the desired buffer for 10-20 min on the microscope stage before initiating an experiment. Temperature was maintained at $37^{\circ} \mathrm{C}$ using an air-curtain incubator (Laboratory Products, Inc., Boston, MA). Baseline ratio images were obtained, and $2.5 \mathrm{mM} \mathrm{KCN}, 0.5 \mathrm{mM}$ IAA, and $5 \mu \mathrm{M}$ propidium iodide were added. We have previously shown in hepatocyte suspensions that $\mathrm{KCN}$ and IAA depleted ATP by $>95 \%$ within $5 \mathrm{~min}$. The rate and extent of ATP depletion was indistinguishable in mildly acidotic (pH 6.4) as compared with neutral (pH 7.4) medium (7). Ratio images were then obtained at frequent intervals. Loss of cellular viability (cell death) was identified by abrupt leakage of BCECF and coincident nuclear staining by propidium iodide.

Intracellular buffering capacity. Hepatocytes were washed free of $\mathrm{KRH}$ buffer by centrifugation for $2 \mathrm{~min}$ at $50 \mathrm{~g}$ and resuspended in $0.15 \mathrm{M} \mathrm{KCl}$ repeated twice. The washed hepatocyte suspension (10 $\times 10^{6} / \mathrm{ml}$ ) was titrated with $\mathrm{HCl}$ between $\mathrm{pH} 7.5$ and 6.0 in the presence of $25 \mu \mathrm{M}$ nigericin at $37^{\circ} \mathrm{C}$. pH was measured with constant stirring using a combination electrode (model 39525; Beckman Instruments, Fullerton, CA) and a pH meter (model 130; Corning Medical Div., Corning Glass Works, Medfield, MA). In parallel experiments, titrations of cell free supernatants were also performed. The difference between the buffering capacities of the cell suspension and cell-free supernatant was taken as the specific cellular buffering capacity. Cellular buffering capacity in millimolar per $\mathrm{pH}$ unit was calculated by dividing acid equivalents added per $\mathrm{pH}$ unit change by cell volume assuming a cell volume of $4.8 \mu \mathrm{l} / 10^{6}$ hepatocytes (19).

Materials. BCECF and BCECF-AM were purchased from Molecular Probes, Inc. (Eugene, OR); rhodamine 123 was obtained from Kodak Laboratories (Rochester, NY); 3-( $N$-morpholino)-propanesulfonic acid (MOPS), amiloride, 4,4'-diisothiocyano-2,2'-stilbene disulfonate (DIDS), propidium iodide, sodium gluconate, glucuronic acid, nigericin, monensin, BSA fraction $\mathrm{V}$, rhodamine-dextran (average molecular mass $71.2 \mathrm{kD}$ ), and choline chloride from Sigma Chemical Co. (St. Louis, MO); IAA from Chemical Dynamics Corp. (South Plainfield, NJ); KCN from Fisher Scientific Co. (Fair Lawn, NJ); Waymouth's medium MB 752/1 from GIBCO Laboratories (Grand Island, NY); type II collagenase from Cooper Biomedicals (Malvern, PA); Hepes from Boehringer-Mannheim Biochemicals (Indianapolis, IN); MES from Calbiochem-Behring Corp. (La Jolla, CA); rhodamine-labeled carboxylate microspheres $(0.1 \mu \mathrm{m})$ from Polysciences, Inc. 
(Warrington, PA); and insulin from E. R. Squibb and Son, (Princeton, $\mathrm{NJ})$. Other reagents were of analytical grade obtained from the usual commercial sources.

\section{Results}

Subcellular localization of BCECF in single, cultured hepatocytes. Fluorescent probes loaded into cells as acetoxymethyl esters may localize into cellular compartments other than the cytosol (20-23). Therefore, we developed a method, using MDVM, to localize fluorescent probes in single cells. The principle of our approach was to load cells with additional fluorescent probes specific for various intracellular compartments: rhodamine dextran for lysosomes, rhodamine microspheres for endosomes, and rhodamine 123 for mitochondria. Cellular compartments were then sequentially opened by increasing concentrations of detergent (24): $20 \mu \mathrm{M}$ digitonin for cytosol, $100 \mu \mathrm{M}$ digitonin for lysosomes and endosomes, and $0.1 \%$ Triton X-100 for mitochondria. The extent and amount of colocalization of BCECF with the various markers of specific compartments was determined by MDVM. BCECF-loaded cells (Figs. $1 A, 2 A$, and $3 A$ ) were coloaded with rhodaminedextran (Fig. $1 B$ ) or rhodamine-microspheres (Fig. $2 B$ ), or rhodamine 123 was added after digitonin (Fig. $3 C$ ). $20 \mu \mathrm{M}$ digitonin produced a $>96 \%$ release of BCECF fluorescence (Figs. $1 C$ and $2 C$, Table I), but rhodamine-dextran and rhodamine microsphere fluorescence remained unchanged (Figs. $1 D$ and $2 D$ ). As digitonin increased from 20 to $100 \mu \mathrm{M}$, no additional loss of BCECF fluorescence occurred (Figs. $1 E$ and $2 E$, Table I). At the higher digitonin concentration, lysosomal and endosomal contents were released (Figs. $1 F$ and $2 E$ ) but mitochondria remained intact (Fig. $3 C$ ). After $0.1 \%$ Triton $\mathrm{X}-100$, no rhodamine 123 fluorescence could be detected (data not shown). These results demonstrate the absence of BCECF localization to lysosomes, endosomes, mitochondria and, presumably, to other membraneous organelles. Thus, BCECF is localized virtually completely to the cytosol (including nucleoplasm).

Concentration of BCECF in loaded hepatocytes. Freshly isolated hepatocytes were loaded with $5 \mu \mathrm{M}$ BCECF-AM for 30 min at $37^{\circ} \mathrm{C}$ in $\mathrm{KRH}$ buffer, washed, and exposed to 100 $\mu \mathrm{M}$ digitonin or $0.1 \%$ Triton $\mathrm{X}-100$. The lysed cells were centrifuged (1,000 g-min) and fluorescence of the supernatant measured compared with BCECF standards after subtracting the background fluorescence of digitonin and Triton X-100. Digitonin and Triton X-100 released BCECF to a nearly identical degree confirming the nonmitochondrial localization of BCECF. Assuming a cellular volume of $4.8 \mu \mathrm{l} / 10^{6}$ cells and that $80 \%$ of cell volume is cytosolic (19), BCECF concentration in the cytosol was $110 \mu \mathrm{M}$.

Relationship between $\mathrm{pH}_{o}$ and $\mathrm{pH}_{i}$ under normoxic conditions. $\mathrm{pH}_{\mathrm{i}}$ was quantified in individual cultured hepatocytes at different $\mathrm{pH}_{\mathrm{o}}$ by ratio imaging of $\mathrm{BCECF}$ fluorescence using MDVM. In normoxic hepatocytes, $\mathrm{pH}_{\mathrm{i}}$ increased or decreased as $\mathrm{pH}_{\mathrm{o}}$ increased or decreased (Fig. 4). $\mathrm{pH}_{\mathrm{i}}$ was slightly more alkaline than $\mathrm{pH}_{\mathrm{o}}$ when $\mathrm{pH}_{\mathrm{o}}$ was between 6 and 7 and slightly more acidic than $\mathrm{pH}_{\mathrm{o}}$ when $\mathrm{pH}_{\mathrm{o}}$ was between 7 and 7.4. These findings agree with earlier reports for hepatocytes and gastric epithelial cells using nuclear magnetic resonance spectroscopy of $\left[{ }^{19} \mathrm{~F}\right]$ difluoromethylamine and using BCECF, respectively, to measure $\mathrm{pH}_{\mathrm{i}}(25,26)$.
Decrease of $p H_{i}$ during chemical hypoxia. To mimic ATP depletion occurring in ischemia, $2.5 \mathrm{mM} \mathrm{KCN}$ and $0.5 \mathrm{mM}$ IAA were added to cultured hepatocytes incubated in KRHB buffer. KCN and IAA block cellular ATP formation by inhibition of oxidative phosphorylation and glycolysis, respectively (11). This condition of chemical hypoxia causes a $95 \%$ decrease of ATP within $5 \mathrm{~min}$ (7). At $\mathrm{pH}_{\mathrm{o}}$ of 7.4, $\mathrm{pH}_{\mathrm{i}}$ decreased $1.0 \mathrm{pH}$ unit within $10 \mathrm{~min}$ of the onset of chemical hypoxia (Fig. 5). The decrease of $\mathrm{pH}_{\mathrm{i}}$ was sustained for another 20-30 min. After a total of 30-40 min, $\mathrm{pH}_{\mathrm{i}}$ began to increase, and cell death followed shortly, as evidenced by leakage of BCECF and coincident nuclear staining with propidium iodide (asterisk in Fig. 5). Identical changes of $\mathrm{pH}_{\mathrm{i}}$ occurred in bicarbonate-free buffer (KRH) (Fig. 5). Extracellular pH remained at 7.4 throughout these experiments. In view of the above findings and to manipulate more freely extracellular $\mathrm{pH}$ and ion content, bicarbonate-free KRH buffer was used in most subsequent experiments.

In separate experiments, we monitored BCECF content during the late rise in $\mathrm{pH}_{\mathrm{i}}$ by monitoring $\mathrm{BCECF}$ fluorescence at the $\mathrm{pH}$-insensitive wavelength, $440 \mathrm{~nm}$ (Fig. 6). Accompanying the late rise in $\mathrm{pH}_{\mathrm{i}}, \mathrm{BCECF}$ began to leak from the cell at an accelerated rate indicative of rapidly increasing plasma membrane permeability. This metastable state appears to mark the beginning of the onset of cell death.

Spatial distribution of $\mathrm{pH}_{i}$. The spatial distribution of intracellular $\mathrm{pH}$ before and during chemical hypoxia was determined and represented as color maps. In the experiment shown in Fig. 7, basal $\mathrm{pH}_{\mathrm{i}}$ was relatively uniform throughout the cell and averaged $\sim 7.35$ (Fig. $7 A$ ). After 16-38 min of chemical hypoxia, average $\mathrm{pH}_{\mathrm{i}}$ was 6.4 (Fig. $7, B$ and $C$ ). This intracellular acidosis was homogeneous throughout the cytosol including the cell surface blebs. After $44 \mathrm{~min}, \mathrm{pH}_{\mathrm{i}}$ had risen to 6.7 , but no regional or spatial foci of increasing $\mathrm{pH}$ were detected (Fig. $7 \mathrm{D}$ ). The inability to detect a regional focus of increasing $\mathrm{pH}$ indicates that either the plasma membrane permeability barrier had become diffusely leaky or that the diffusion of hydrogen ions was too rapid to detect a focal area of rising $\mathrm{pH}$. After $46 \mathrm{~min}, \mathrm{pH}_{\mathrm{i}}$ had increased to 7.1, and accelerated leakage of BCECF was evidenced by erosion of the image indicating the onset of irreversible cell injury (Fig. $7 E$ ). After $>46$ min, BCECF leakage was so great that images could no longer be obtained (Fig. $7 F$ ).

Relationship between $p H_{o}$ and $p H_{i}$ during chemical hypoxia. Exposure of hepatocytes to acidic buffer simultaneously with $\mathrm{KCN}$ and IAA produced a slightly greater drop in $\mathrm{pH}_{\mathrm{i}}$ and prolonged the plateau phase of intracellular acidosis (Fig. 8). At $\mathrm{pH}_{\mathrm{o}} 6.8$ and $6.4, \mathrm{pH}_{\mathrm{i}}$ dropped to 6.3 and 6.2 , respectively, after $10 \mathrm{~min}$ of chemical hypoxia and the duration of decreased $\mathrm{pH}_{\mathrm{i}}$ was prolonged an additional 20-30 minutes. Cell viability was also prolonged to a similar degree, and the onset of cell death again followed a relatively sharp increase of $\mathrm{pH}_{\mathrm{i}}$.

Role of anion and cation exchangers. When extracellular $\mathrm{Na}^{+}$was replaced isosmotically with choline to inhibit plasma membrane $\mathrm{Na}^{+} / \mathrm{H}^{+}$exchange (27), cell survival and the plateau phase of intracellular acidosis were both sustained an additional $20 \mathrm{~min}$ (Fig. 9). Amiloride, which inhibits the $\mathrm{Na}^{+} / \mathrm{H}^{+}$exchange carrier (27), also produced an increase of cell survival and prolongation of the plateau phase of intracellular acidosis. With both choline and amiloride, cytosolic $\mathrm{pH}$ again rose shortly before the onset of cell death. The late rise in 

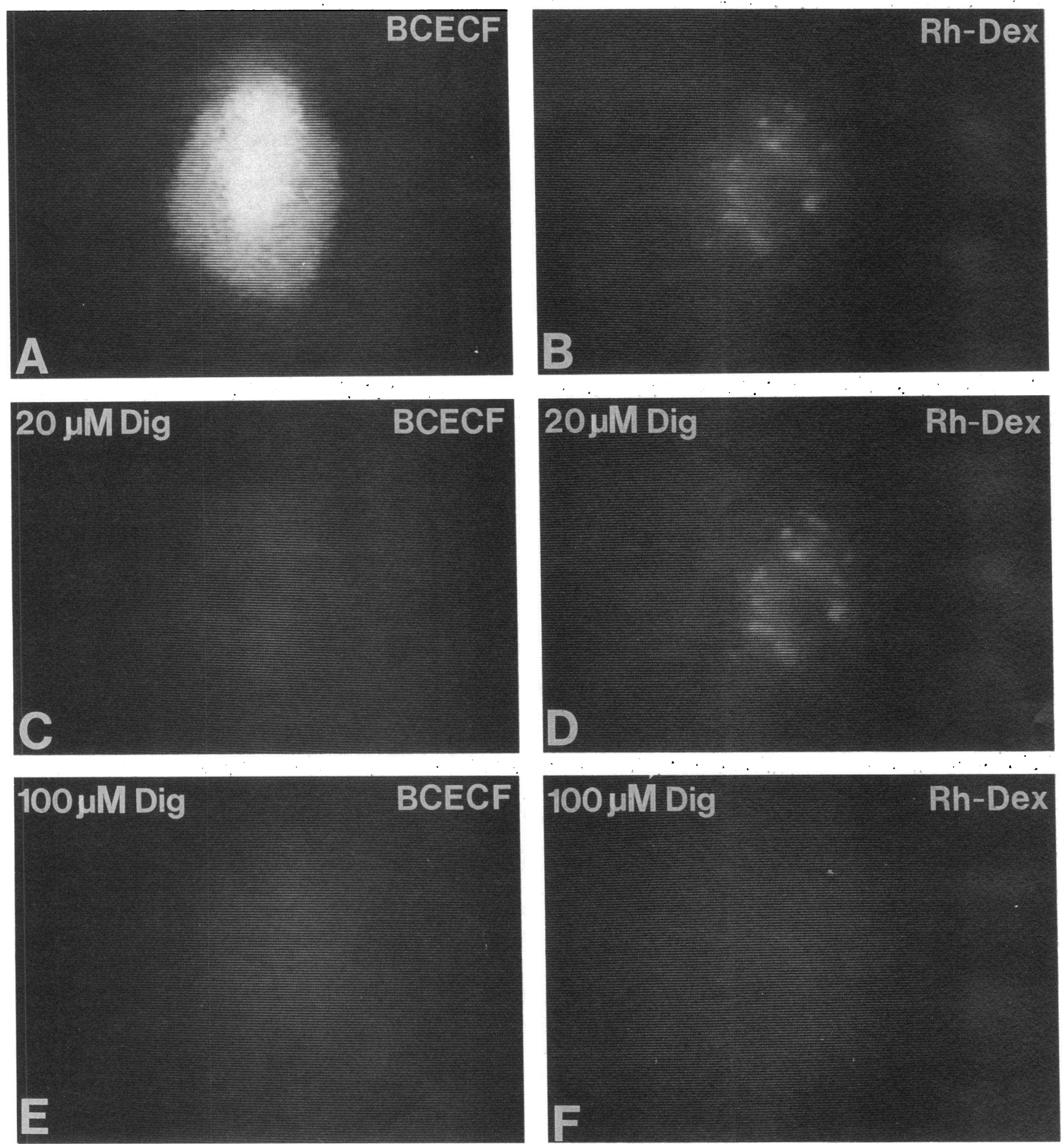

Figure 1. Subcellular localization of BCECF by MDVM: lysosomes. A 1-d cultured hepatocyte loaded previously with rhodamine dextran (see Methods) was loaded additionally with BCECF. BCECF fluorescence from the cell was diffuse $(A)$, whereas rhodamine-dextran fluorescence was punctate-consistent with the localization of the latter to secondary lysosomes $(B)$. After $20 \mu \mathrm{M}$ digitonin, virtually all BCECF fluorescence was released $(C)$, but rhodamine-dextran fluorescence was unchanged $(D)$. After $100 \mu \mathrm{M}$ digitonin, no additional loss of $\mathrm{BCECF}$ fluorescence occurred $(E)$, although rhodamine-dextran fluorescence was lost entirely $(F)$.

intracellular $\mathrm{pH}$ preceding loss of cell viability thus was not due to $\mathrm{Na}^{+} / \mathrm{H}^{+}$exchange. Monensin, which catalyzes $\mathrm{Na}^{+} / \mathrm{H}^{+}$ exchange (17), collapsed the $\mathrm{pH}$ gradient across the plasma membrane and shortened cell survival by $\sim 40$ min (Fig. 9). These experiments demonstrate that intracellular acidosis protects against cell death during ATP depletion, whereas more alkaline $\mathrm{pH}_{\mathrm{i}}$ accelerates the lethal process.
DIDS, an inhibitor of $\mathrm{Cl}^{-} / \mathrm{HCO}_{3}^{-}$exchange (18), did not affect these changes in $\mathrm{pH}_{\mathrm{i}}$ after $\mathrm{KCN}$ plus IAA (data not shown). However, substitution of gluconate for $\mathrm{Cl}^{-}$accelerated the onset of cell death during chemical hypoxia and caused $\mathrm{pH}_{\mathrm{i}}$ to rise steadily after an initial acidification (Fig. 10). Addition of $15 \mathrm{mM} \mathrm{HCO}_{3}^{-}$to this chloride-free buffer abolished the cytosolic acidification after $\mathrm{KCN}$ and IAA, and cell death oc- 

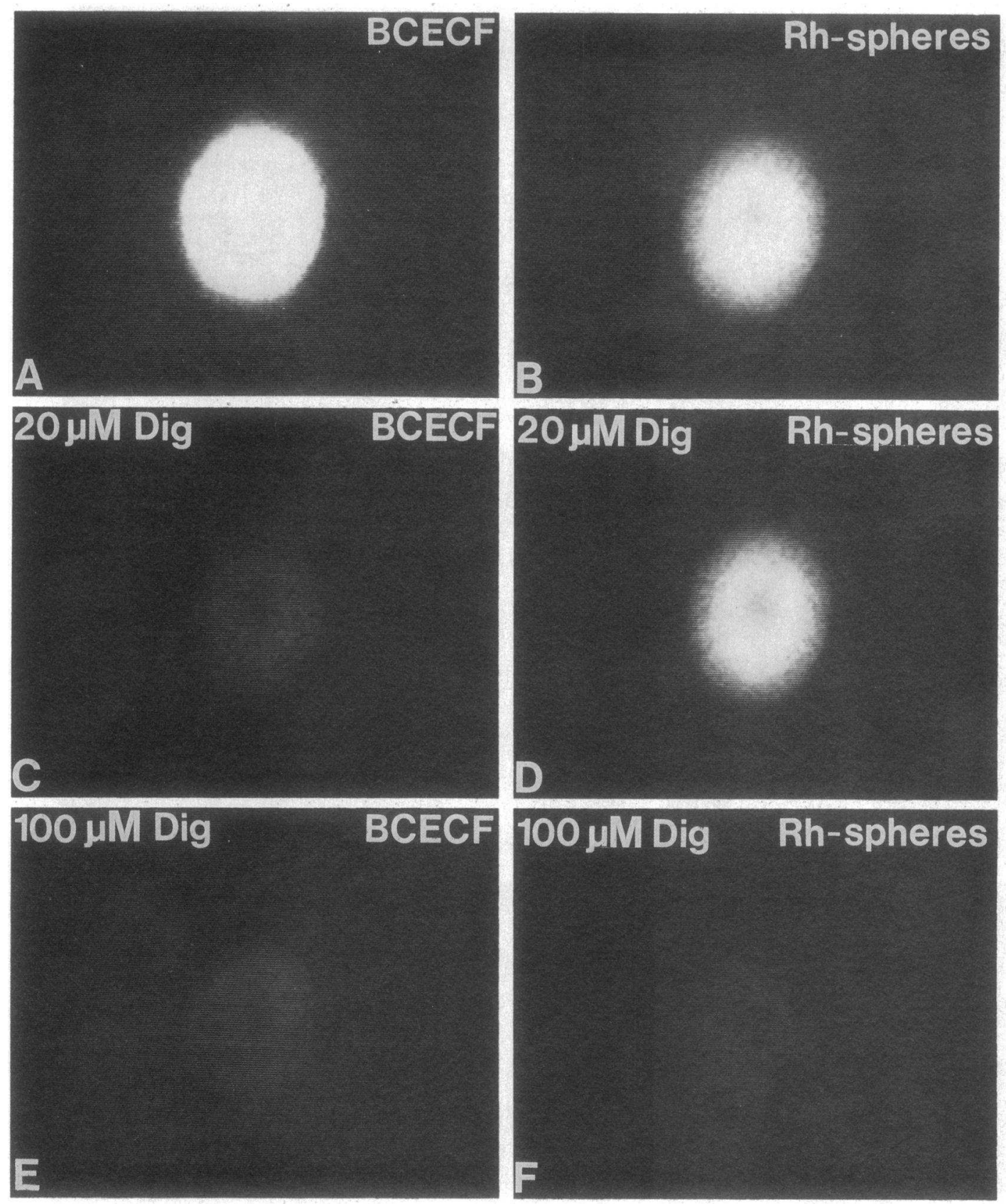

Figure 2. Subcellular localization of BCECF by MDVM: endosomes. A 1-d cultured hepatocyte was loaded with both BCECF and $0.1-\mu \mathrm{m}$ rhodamine-labeled latex microspheres. The cell was diffusely labeled with both probes ( $A$ and $B$ ). After $20 \mu \mathrm{M}$ digitonin, virtually all BCECF fluorescence was released from the cell $(C)$, but rhodamine-microsphere fluorescence remained intact $(D)$. After $100 \mu \mathrm{M}$ digitonin, no additional loss of BCECF fluorescence occurred $(E)$, but rhodamine-microsphere fluorescence disappearance was complete $(F)$.

curred even more rapidly (Fig. 10). DIDS added to this $\mathrm{HCO}_{3}^{-}$-containing, $\mathrm{Cl}^{-}$-free buffer restored the characteristic decrease of $\mathrm{pH}_{\mathrm{i}}$ and plateau phase of intracellular acidosis observed in KRH buffer and delayed the onset of cell death (Fig. 10). These findings are consistent with an anion carrier-mediated exchange of intracellular $\mathrm{Cl}^{-}$for extracellular $\mathrm{HCO}_{3}^{-}$in $\mathrm{HCO}_{3}^{-}$-containing, $\mathrm{Cl}^{-}$-free buffer. This exchange removes acid equivalents from the cells, prevents cytosolic acidification during chemical hypoxia, and accelerates the onset of cell death.

Blebbing and the onset of cell death. Cell surface membrane blebbing is an early consequence of hypoxic hepatocellular injury $(11,28)$. To determine whether blebbing was retarded at protective acidic $\mathrm{pH}_{\mathrm{o}}$, the onset of blebbing was scored over time from time-lapse video recordings of cultured hepatocytes viewed by phase microscopy. Acidic $\mathrm{pH}_{\mathrm{o}}$ of 6.4 had a modest effect in delaying the onset of blebbing (Fig. 11). At $\mathrm{pH}_{\mathrm{o}}$ of $7.4,50 \%$ of cells blebbed after $12 \mathrm{~min}$, whereas at $\mathrm{pH}_{\mathrm{o}}$ 6.4, half-maximal onset of blebbing occurred after 20 min. Furthermore, growth of blebs did not appear to be retarded at acidotic pH (data not shown).

Intracellular buffering capacity. Intracellular buffering capacity was determined in $\mathrm{pH}$ titrations with $25 \mu \mathrm{M}$ nigericin. This ionophore in high $\mathrm{K}^{+}$buffer equilibrates intracellular and extracellular $\mathrm{pH}(15,18)$. As acid was added to a concentrated cell suspension, $\mathrm{pH}$ decreased rapidly and then partially recovered over several seconds (Fig. 12, trace $A$ ). This partial recovery was not observed in cell-free supernatants (Fig. 12, trace $B$ ) and was the consequence of internal buffering by the cells. From the difference in buffering capacity between cell suspen- 

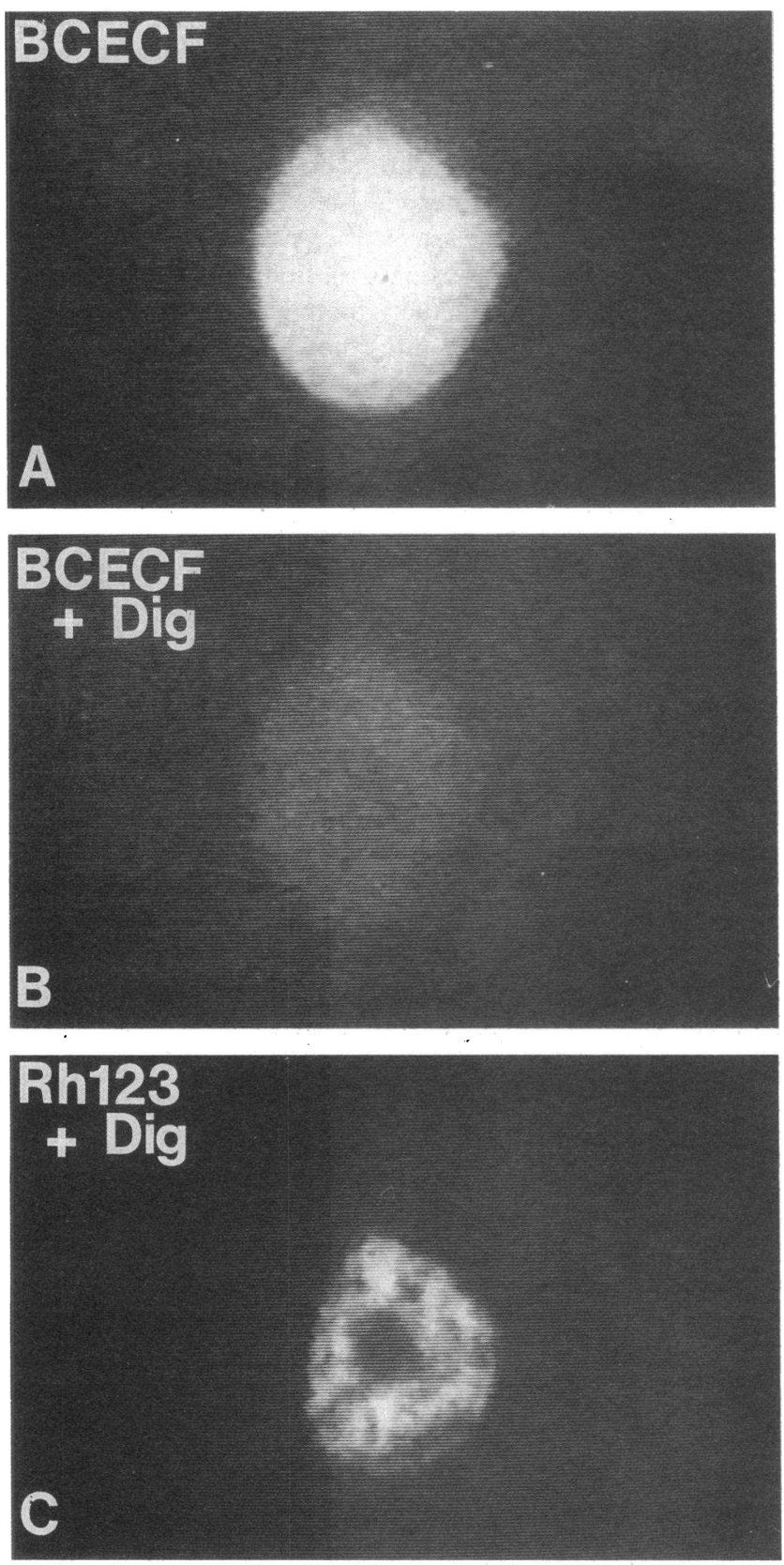

Figure 3. Subcellular localization of BCECF by MDVM: mitochondria. A cultured hepatocyte was loaded with BCECF and displayed diffuse fluorescence $(A)$. After addition of $100 \mu \mathrm{M}$ digitonin in $\mathrm{Ca}^{2+}$ free buffer containing $5 \mathrm{mM}$ succinate, virtually all BCECF fluorescence disappeared $(B)$. Rhodamine 123 was subsequently added to demonstrate the punctate fluorescence of mitochondria $(C)$.

sions and cell-free supernatants, an intracellular buffering capacity of $26 \pm 3 \mathrm{mM} / \mathrm{pH}$ unit (mean $\pm \mathrm{SD}, n=6$ ) was calculated.

\section{Discussion}

In this study, we determined the relationships between $\mathrm{pH}_{\mathrm{o}}$, $\mathrm{pH}_{\mathrm{i}}$, and loss of cell viability in isolated rat hepatocytes during ATP depletion. Intracellular acidosis developed rapidly in hepatocytes during ATP depletion and was sustained until shortly before cell death. Furthermore, intracellular acidosis
Table I. BCECF Release from Cultured Hepatocytes by Digitonin and Triton $X-100$

\begin{tabular}{lc}
\multicolumn{1}{c}{ Addition } & Relative fluorescence \\
\hline None & $100 \%$ \\
$20 \mu \mathrm{M}$ digitonin & $3.5 \pm 2.8 \%$ \\
$100 \mu \mathrm{M}$ digitonin & $<1 \%$ \\
$0.1 \%$ Triton X-100 & $<1 \%$ \\
\hline
\end{tabular}

Cultured hepatocytes were loaded with BCECF as described in Methods. BCECF fluorescence at $440 \mathrm{~nm}$ was quantitated in single cells before and after treatment with detergent using MDVM. Data represent mean $\pm \mathrm{SE}$ for six experiments.

protected hepatocytes against cell death during ATP depletion. This conclusion is based on several observations. Maneuvers that prolonged and/or increased intracellular acidosis, such as inhibition of $\mathrm{Na}^{+} / \mathrm{H}^{+}$exchange and placing the cells in mildly acidic $\mathrm{pH}_{\mathrm{o}}$, also prolonged cell survival. Conversely, manipulations that prevented a decrease in $\mathrm{pH}_{\mathrm{i}}$ potentiated cell killing, such as monensin or substitution of gluconate and bicarbonate for chloride in the extracellular buffer. Finally, a significant rise in $\mathrm{pH}_{\mathrm{i}}$ preceded the onset of irreversible cell injury in all instances.

In hypoxia as in ischemia, ATP formation from oxidative phosphorylation is inhibited completely due to oxygen deprivation. In the absence of glycolytic substrate, ATP is rapidly depleted. In this study, we inhibited oxidative phosphorylation and glycolysis with KCN and IAA to duplicate the ATP depletion of anoxia, a model that we call chemical hypoxia (11). This approach avoids the elaborate technical requirements for maintaining strict anaerobiosis on a microscope stage and produces a consistent pattern of ATP depletion and cell injury (7). IAA also eliminates the variable of glycolytic ATP forma-

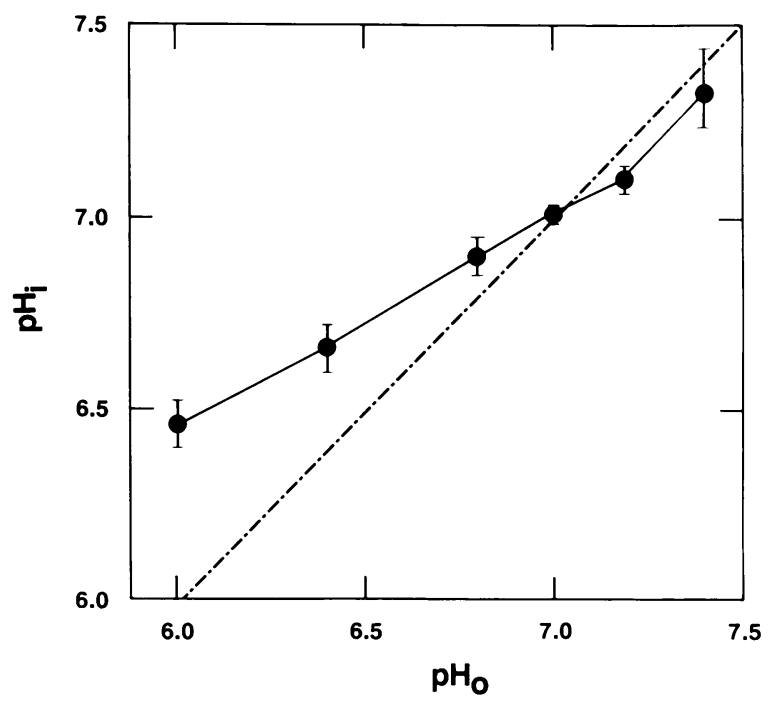

Figure 4. Relationship between cytosolic $\mathrm{pH}\left(\mathrm{pH}_{\mathrm{i}}\right)$ and extracellular $\mathrm{pH}\left(\mathrm{pH}_{\mathrm{o}}\right)$ in single, cultured hepatocytes. $\mathrm{pH}_{\mathrm{i}}$ was determined by ratio imaging of $\mathrm{BCECF}$ fluorescence using MDVM. Hepatocytes were incubated in $\mathrm{KRH}$ buffer at the selected $\mathrm{pH}_{\mathrm{o}}$ for $20 \mathrm{~min}$. The dashed line represents the equality of $\mathrm{pH}_{\mathrm{i}}$ and $\mathrm{pH}_{\mathrm{o}}$. Data points are means $\pm \mathrm{SE}$ for five or more experiments. 


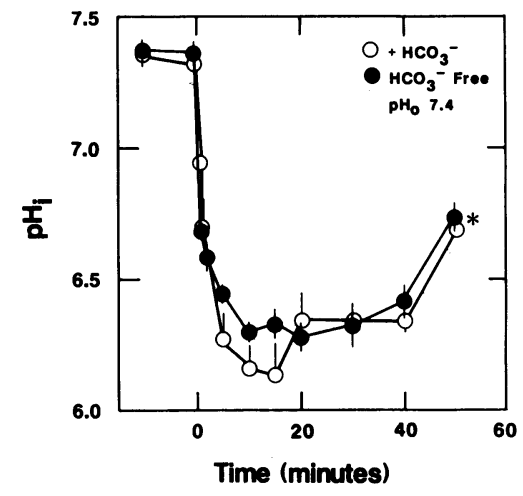

Figure 5. Decrease in cytosolic $\mathrm{pH}\left(\mathrm{pH}_{\mathrm{i}}\right)$ in individual cultured hepatocytes during chemical hypoxia in the presence or absence of extracellular bicarbonate. $\mathrm{pH}_{\mathrm{i}}$ was determined by ratio imaging of $\mathrm{BCECF}$ fluorescence using MDVM before and during chemical hypoxia with $2.5 \mathrm{mM} \mathrm{KCN}$ and $0.5 \mathrm{mM}$ IAA. He-

patocytes were incubated in (๑) bicarbonate-free KRH buffer or in (O) bicarbonate-containing KRHB buffer. Cell death $\left(^{*}\right)$ was identified by nuclear labeling with $5 \mu \mathrm{M}$ propidium iodide and coincident leakage of $\mathrm{BCECF}$ from the cell at the $\mathrm{pH}$-insensitive wavelength $(440 \mathrm{~nm})$. Data points are means \pm SE for five or more experiments.

tion using endogenous glycogen as a substrate, a factor that is otherwise quite difficult to control in hepatocytes $(7,29)$.

$\mathrm{BCECF}$ is well established as a fluorescent probe of intracellular $\mathrm{pH}(10,15,18)$. BCECF is loaded into cells as its acetoxymethyl ester. Endogenous esterases are assumed to hydrolyze BCECF-AM to liberate free probe in the cytosol. However, we and others have described localization of fluorescent probes including BCECF into other cellular compartments, especially lysosomes and mitochondria (20-23). As the endocytic, lysosomal, and mitochondrial compartments have a different pH from the cytosol, documentation of the subcellular localization of $\mathrm{BCECF}$ with respect to these compartments is essential to the proper interpretation of changes of BCECF fluorescence. Accordingly, we evaluated the subcellular localization of BCECF in 1-d cultured hepatocytes using MDVM. These experiments documented that BCECF loaded into cultured hepatocytes was predominantly localized to the cytosol

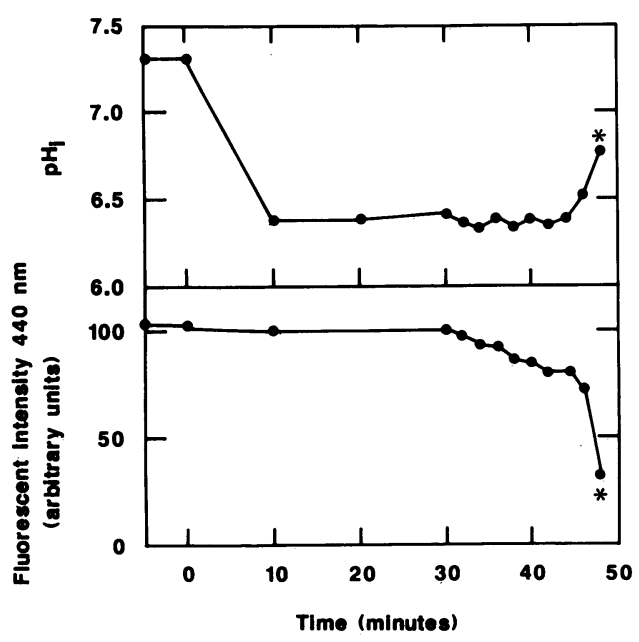

Figure 6. $\mathrm{pH}_{\mathrm{i}}, \mathrm{BCECF}$ release, and the onset of cell death. $(A) \mathrm{pH}_{\mathrm{i}}$ and $(B)$ cellular BCECF content were measured in a single hepatocyte before and during chemical hypoxia in KRH buffer. Experimental conditions were as described in Fig. 5. Intracellular concentration of BCECF was monitored by fluorescence excited at the $\mathrm{pH}$-insensitive wavelength of $440 \mathrm{~nm}$. One experiment is representative of three.
(>95\%) with little accumulation $(<5 \%)$ into mitochondria, lysosomes, and endosomes.

Intracellular pH dropped to 6.3-6.5 after $10 \mathrm{~min}$ of chemical hypoxia. A similar decrease of tissue $\mathrm{pH}$ has been described for ischemic canine myocardium and in rat kidney during normothermic and hypothermic ischemic storage $(30,31)$. Previously, a smaller decrease of $\mathrm{pH}_{\mathrm{i}}$ was reported in hepatocyte suspensions during anoxia $(6,8)$. In the latter studies, the decline of ATP was considerably more gradual (62 and 71\%, respectively, after 5 and $49 \mathrm{~min}$ ) than observed here during chemical hypoxia (95\% after $5 \mathrm{~min}$ ). As discussed below, protons liberated by ATP hydrolysis may be largely responsible for acidosis during anoxia. Moreover, this work used 1-d cultured hepatocytes. In freshly isolated hepatocytes cultured $<2$ $h$, we have found a decrease of $\mathrm{pH}_{\mathrm{i}}$ after chemical hypoxia of $\sim 0.5$ units (data not shown) as compared with 1 unit in $1-\mathrm{d}$ cultured hepatocytes. This observation suggests that the plasma membranes of freshly isolated hepatocytes are relatively more permeable and less able to maintain a $\mathrm{pH}$ gradient than the plasma membranes of 1-d cultured cells.

From a basal $\mathrm{pH}_{\mathrm{i}}$ of 7.34 at $\mathrm{pH}_{\mathrm{o}}$ of $7.4, \mathrm{pH}_{\mathrm{i}}$ decreased by 1.0 unit in 10 min after addition of $\mathrm{KCN}$ plus IAA. After another $30 \mathrm{~min}, \mathrm{pH}_{\mathrm{i}}$ began to rise and cell death ensued after 10 more minutes. We investigated the respective contributions of the $\mathrm{Na}^{+} / \mathrm{H}^{+}$and $\mathrm{Cl}^{-} / \mathrm{HCO}_{3}^{-}$plasma membrane exchangers to these changes in $\mathrm{pH}_{\mathrm{i}}$ as both are important for $\mathrm{pH}$ regulation by hepatocytes $(32,33)$. $\mathrm{Na}^{+} / \mathrm{H}^{+}$exchange would be expected to increase $\mathrm{pH}_{\mathrm{i}}$ by removing cytosolic protons in exchange for $\mathrm{Na}^{+}$ions moving down a $\mathrm{Na}^{+}$concentration gradient. Inhibition of $\mathrm{Na}^{+} / \mathrm{H}^{+}$exchange with amiloride or by replacing $\mathrm{Na}^{+}$with choline (removing the inwardly directed $\mathrm{Na}^{+}$gradient) prolonged the duration of intracellular acidosis. This finding suggests that the cation exchanger does catalyze a leak of protons during the hypoxic period. In contrast, monensin, which introduces exogenous $\mathrm{Na}^{+} / \mathrm{H}^{+}$exchange activity to the plasma membrane, collapsed the $\mathrm{pH}$ gradient and potentiated cell killing. Endogenous $\mathrm{Na}^{+} / \mathrm{H}^{+}$exchange activity of normoxic hepatocytes is activated by cytosolic acidification and is sufficiently great to change intracellular $\mathrm{pH}$ in a few minutes (33). In hypoxic hepatocytes, endogenous $\mathrm{Na}^{+} / \mathrm{H}^{+}$ exchange was relatively slow. The activity of the cation exchanger thus appeared to be suppressed during chemical hypoxia. The rise in $\mathrm{pH}_{\mathrm{i}}$ observed just before the onset of cell death was not due to an activation of $\mathrm{H}^{+} / \mathrm{Na}^{+}$exchange, since blocking the exchange by substitution of $\mathrm{Na}^{+}$with choline did not prevent this late rise.

The plasma membrane anion exchanger is normally poised to remove excess $\mathrm{HCO}_{3}^{-}$in exchange for $\mathrm{Cl}^{-}$, thereby preventing alkalinization of the cytosol $(26,32)$. When anion exchange was inhibited with DIDS (18), the changes in $\mathrm{pH}_{\mathrm{i}}$ after $\mathrm{KCN}$ plus IAA were unaffected. Anion exchange thus did not contribute to intracellular acidosis during ATP depletion or to the late rise of $\mathrm{pH}_{\mathrm{i}}$ before the onset of cell death. However, when extracellular $\mathrm{Cl}^{-}$was replaced with gluconate plus $\mathrm{HCO}_{3}^{-}, \mathrm{pH}_{\mathrm{i}}$ did not decrease during ATP depletion and cell death was accelerated. This was the only situation where bicarbonate altered $\mathrm{pH}_{\mathrm{i}}$ during ATP depletion. Under these conditions (intracellular $\mathrm{Cl}^{-}>$extracellular $\mathrm{Cl}^{-}$), the chloride gradient favored loss of intracellular $\mathrm{Cl}^{-}$in exchange for $\mathrm{HCO}_{3}^{-}$. Therefore, we attribute the effects of gluconate and $\mathrm{HCO}_{3}^{-}$on $\mathrm{pH}_{\mathrm{i}}$ during chemical hypoxia to reverse anion transport, i.e., exchange of extracellular $\mathrm{HCO}_{3}^{-}$for intracellular $\mathrm{Cl}^{-}$. 

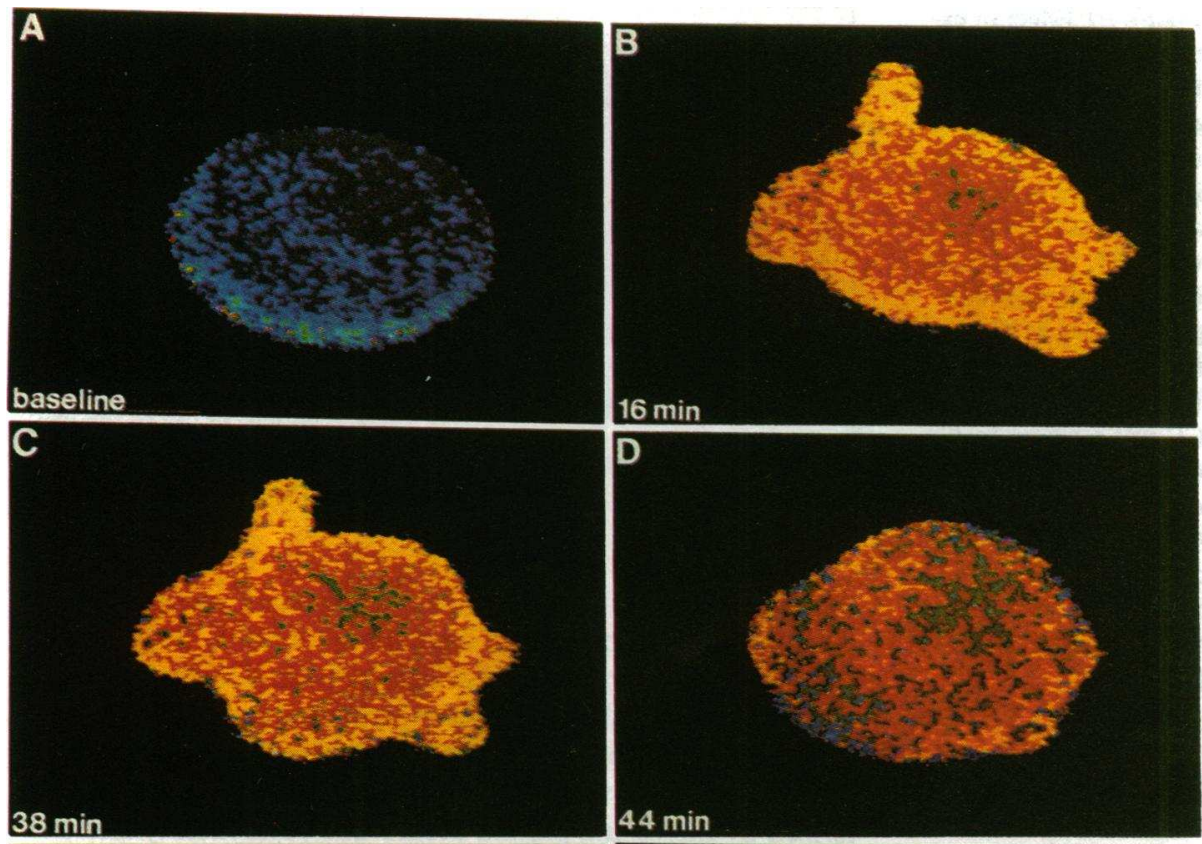

Figure 7. Spatial distribution of $\mathrm{pH}_{\mathrm{i}}$ in a single, cultured hepatocyte during chemical hypoxia. Basal $\mathrm{pH}_{\mathrm{i}}$ was $\mathbf{7 . 3 5}$
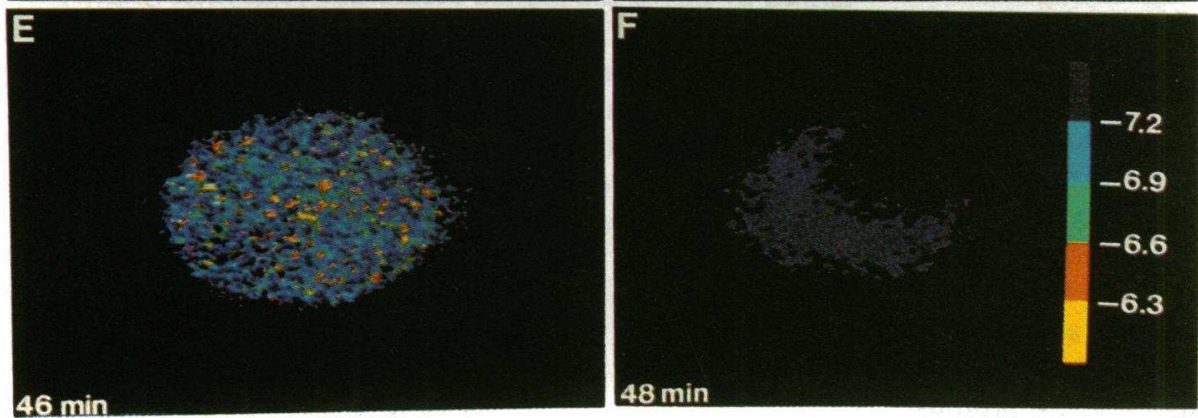

before chemical hypoxia as represented by blue $(A)$. After 16-38 min of chemical hypoxia, average $\mathrm{pH}_{\mathrm{i}}$ was 6.4 as represented by the colors orange and yellow $\left(B\right.$ and $C$ ). After $\sim 44 \mathrm{~min}, \mathrm{pH}_{\mathrm{i}}$ had risen to $6.7(D)$. After $46 \mathrm{~min}, \mathrm{pH}_{\mathrm{i}}$ was 7.1 and leakage of BCECF was evidenced by erosion of the image $(E) .2$ min later, the cell was dead, as shown by loss of cellular fluorescence $(F)$. Experimental conditions were as described in Fig. 5.

This interpetation is supported by the observation that in this buffer, DIDS restored the normal intracellular acidification of ATP depletion.

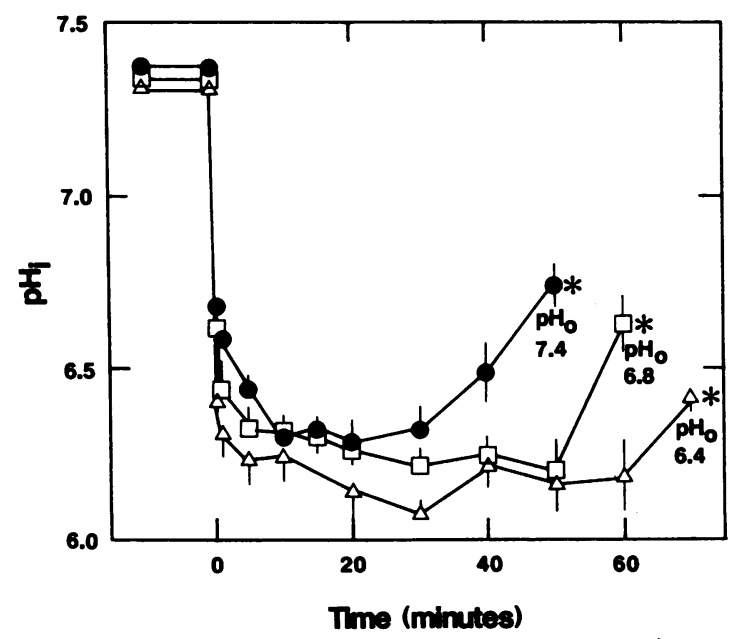

Figure 8. $\mathrm{pH}_{\mathrm{i}}$ single, cultured hepatocytes during chemical hypoxia at different $\mathrm{pH}_{0} \cdot \mathrm{pH}_{\mathrm{o}}$ was decreased from 7.4 to $6.8(\square)$ or $6.4(\Delta)$ or not changed ( $(\bullet)$ simultaneously with the addition of $\mathrm{KCN}$ and IAA. Other conditions were as described in Fig. 5. Data points are means $\pm \mathrm{SE}$ for three or more experiments.
A preliminary report has suggested that hepatocytes may also regulate $\mathrm{pH}_{\mathrm{i}}$ via $\mathrm{Na}^{+} / \mathrm{HCO}_{3}^{-}$cotransport (34). In our experiments, the magnitude and duration of intracellular acidosis during chemical hypoxia was the same in $\mathrm{Na}^{+}$-containing buffer whether or not $\mathrm{HCO}_{3}^{-}$was present. $\mathrm{Na}^{+} / \mathrm{HCO}_{3}^{-}$co-

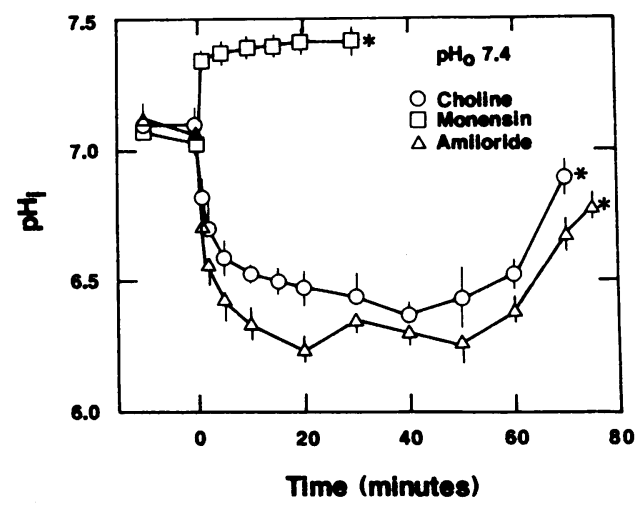

Figure 9. Effect of inhibition and promotion of $\mathrm{Na}^{+} / \mathrm{H}^{+}$exchange on $\mathrm{pH}_{\mathrm{i}}$ during chemical hypoxia. Cells were incubated in $\mathrm{KRH}$ buffer containing $1 \mathrm{mM}$ amiloride $(\Delta), \mathrm{KRH}$ buffer where $\mathrm{Na}^{+}$was replaced isosmotically with choline (0) or in KRH buffer containing $105 \mathrm{mM}$ choline and $10 \mathrm{mM} \mathrm{Na}^{+}$plus $10 \mu \mathrm{M}$ monensin ( $\square$ ). Other conditions were as described in Fig. 5. Data points are means \pm SE for three experiments. 


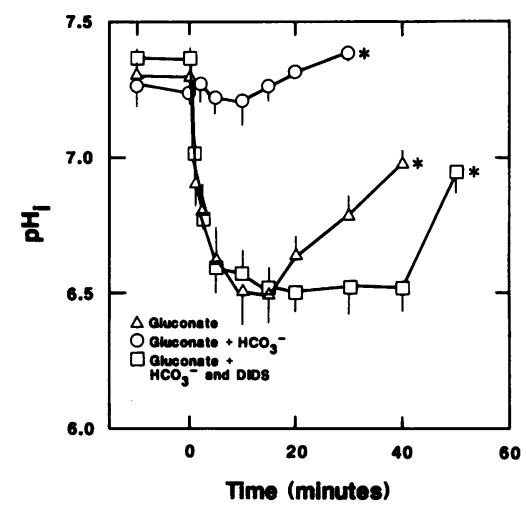

Figure 10. Effect of extracellular anions and DIDS on $\mathrm{pH}_{\mathrm{i}}$ during chemical hypoxia. Cultured hepatocytes were incubated in bicarbonate-free $\mathrm{KRH}$ buffer, in which $\mathrm{Cl}^{-}$was replaced isosmotically with $(\Delta)$ gluconate or in bicarbonate containing KRHB buffer where $\mathrm{Cl}^{-}$was replaced by gluconate ( $\square$ ) with or without $1 \mathrm{mM}$ (0) DIDS. Other conditions were as described in Fig. 5. Data points are means $\pm S E$ for three experiments.

transport thus did not appear to be occurring in response to the intracellular acidosis of ATP depletion.

The decrease in $\mathrm{pH}_{\mathrm{i}}$ during chemical hypoxia paralleled hydrolysis of ATP. In agreement with arguments by Hochacka and Mommsen (35), we conclude that hydrolysis of nucleoside phosphates is predominantly responsible for intracellular acidosis during hypoxia. In our model, a contribution by lactic acid to intracellular hydrolysis can be excluded, because glyceraldehyde-3-phosphate dehydrogenase in the glycolytic pathway was inhibited by IAA (36). Intracellular buffering capacity for our preparation of hepatocytes was $26 \mathrm{mM}$, in agreement with values reported for other eukaryotic cells (37). Hydrolysis of cellular adenine nucleotides will produce $\sim 9 \mathrm{mM}$ protons (assuming $1 \mathrm{H}^{+}$per hydrolyzed phosphate and hydrolysis of 4.0 mM ATP and 0.5 mM ADP to AMP and phosphate) (8) and thus account for about half of the observed decrease in $\mathrm{pH}_{\mathrm{i}}$. The remainder may be due to hydrolysis of other organic phosphates.

The maintenance across the plasma membrane of a $\mathrm{pH}$ gradient of 1 unit after ATP depletion was unexpected. Jones and co-workers, however, in elegant recent studies, have demonstrated that mitochondrial and plasma membrane potentials and a large number of ion gradients are preserved during anoxia in hepatocytes $(8,38,39)$. Their findings demonstrate

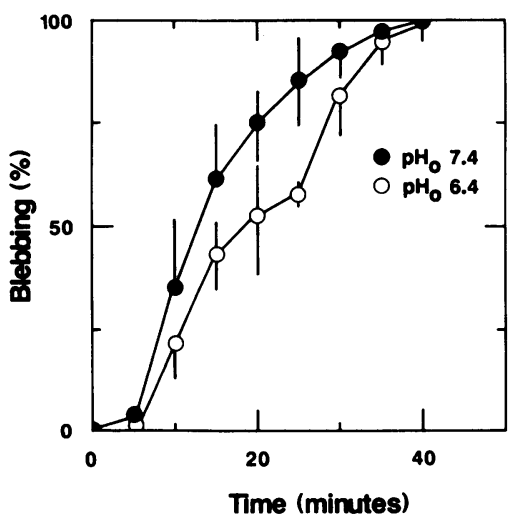

Figure 11. Effect of $\mathrm{pH}_{0}$ on the progression of blebbing in cultured hepatocytes during chemical hypoxia. Cultured hepatocytes ( $>20 /$ field) were monitored for cell blebbing during chemical hypoxia at a (๑) $\mathrm{pH}_{\mathrm{o}}$ of 7.4 or $(0) \mathrm{pH}_{\mathrm{o}} 6.4$. Blebbing was not observed in normoxic hepatocytes observed under identical conditions. Data are means \pm SE for four experiments.

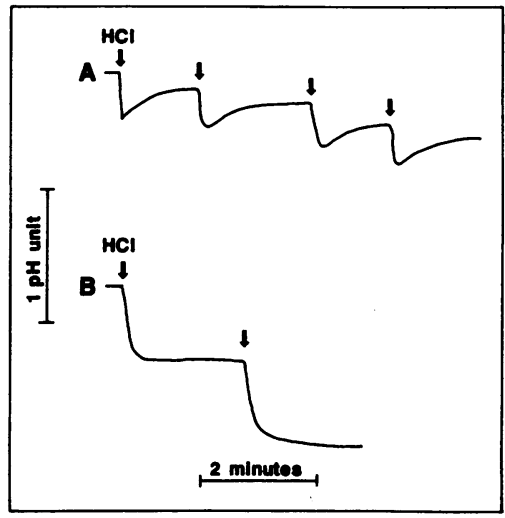

Figure 12. $\mathrm{pH}$ titrations of cell suspensions and cell-free supernatants in the presence of nigericin. 0.5-meq aliquots of acid (arrows) were added to washed hepatocytes $\left(10 \times 10^{6} / \mathrm{ml}\right)$ in $1.5 \mathrm{ml}$ of $0.15 \mathrm{M} \mathrm{KCl}$ containing $25 \mu \mathrm{M}$ nigericin or $(B)$ to the corresponding cell-free supernatant.

that ion permeability of cellular membranes decreases early during anoxia to produce a neahypoxic state $(8,38)$. Our results implicate intracellular acidosis in the initiation and maintenance of this neahypoxic state. Furthermore, we have shown that plasma membrane permeability begins to increase shortly before loss of cell viability creating a metastable state characterized by increasing plasma membrane permeability and rising cytosolic $\mathrm{pH}$. This rapid event marks the transition from viability to cell death.

Mild extracellular acidosis has been shown to be protective against the onset of irreversible injury in hepatocytes during chemical hypoxia (7), and in myocytes, Erhlich ascites tumor cells, kidney tubule cells, and hepatocytes during anoxia $(2,5$,

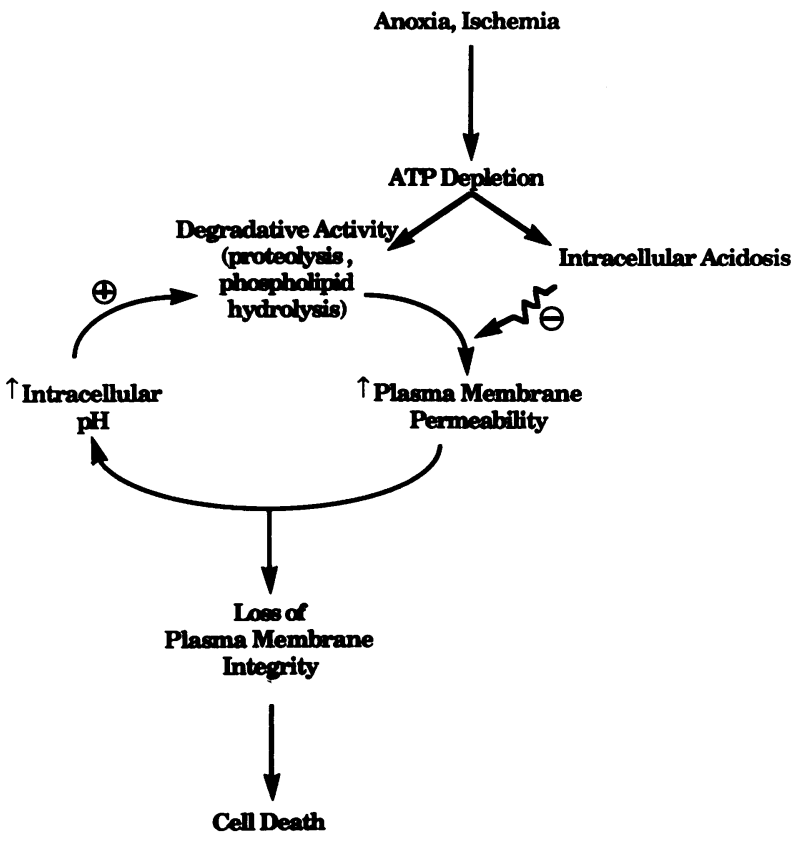

Figure 13. Intracellular $\mathrm{pH}$ and the progression of cell injury during anoxic and ischemic stress. ATP depletion from anoxia or ischemia leads to intracellular acidosis and activation of autolytic enzymes (proteases and phospholipases). Intracellular acidosis protects by inhibiting the activity of the activated enzymes. Inhibition is not complete, and ultimately degradative processes lead to increased plasma membrane permeability. As protons leak from the cell and intracellular $\mathrm{pH}$ rises, the degradative enzymes are no longer inhibited. A positive feedback loop is created that accelerates the increase of plasma membrane permeability and culminates rapidly in cell death. 
6). Our data extend these observations by demonstrating that the protective effect is mediated by $\mathrm{pH}_{\mathrm{i}}$. In general, the greater the intracellular acidification, the greater was the protection. For example, after 5 min of chemical hypoxia at $\mathrm{pH}_{\mathrm{o}}$ of 7.4 , 6.8 , and 6.4, the corresponding values of $\mathrm{pH}_{\mathrm{i}}$ were $6.44,6.32$, and 6.23. Converted to hydrogen ion concentrations, these values were 363,479 , and $589 \mathrm{nM}$, respectively. Thus, large differences of cytosolic hydrogen ion concentration occurred as $\mathrm{pH}_{\mathrm{o}}$ was varied during chemical hypoxia.

The mechanism of the protective effect of intracellular acidosis remains obscure. We have shown previously (7) that acidosis does not inhibit the early hydrolysis of adenine nucleotides in hepatocytes, as has been suggested for myocytes (4). Similarly, Bonventre and co-workers found that extracellular acidosis did not alter hepatocellular ATP depletion during anoxia (6). In addition, we found that acidic $\mathrm{pH}_{\mathrm{i}}$ did not prevent bleb formation and growth, an early morphologic alteration in hepatocellular injury $(11,28)$, although a small retardation in the rate of onset of blebbing was observed.

Our working hypothesis is that intracellular acidosis suppresses autolytic degradative processes (e.g., proteolysis or phospholipid hydrolysis) that are initiated as a consequence of ATP depletion (Fig. 13) (40). Along these lines, we have observed a protective effect of mildly acidic $\mathrm{pH}_{\mathrm{o}}$ against cell death during hepatocellular injury by cystamine (unpublished observations), an injury reported to result from activation of neutral proteases (41). Although inhibited at an acidic intracellular $\mathrm{pH}$, the degradative processes lead ultimately to an increase of plasma membrane permeability causing protons to leak from the cell and $\mathrm{pH}_{\mathrm{i}}$ to rise. A positive feedback loop is created that accelerates the $\mathrm{pH}$-dependent degradative processes, increases membrane permeability further, and culminates rapidly in cell death. The ability of acidic $\mathrm{pH}_{\mathrm{i}}$ to delay cell death during ATP depletion may be analogous to the protective effects of cold temperature which also inhibit degradative processes. Acidic $\mathrm{pH}_{\mathrm{i}}$ thus may induce a cold temperature state in the cell representing a protective adaptation against hypoxic and ischemic stress.

\section{Acknowledgments}

This work was supported in part by grants AG-07218, DK-30874, and HL-35490 from the National Institutes of Health (NIH), and a grantin-aid from the American Heart Association, North Carolina Affiliate. Dr. Gores is a recipient of an Individual National Research Service Award from the NIH and is a Mayo Foundation Scholar.

\section{References}

1. Bing, O. H. L., W. W. Brooks, and J. V. Messer. 1973. Heart muscle viability following hypoxia: protective effect of acidosis. Science (Wash. DC). 180:1297-1298.

2. Altschuld, R. A., J. R. Hostetler, and G. P. Brierley. 1981. Response of isolated rat heart cells to hypoxia, re-oxygenation, and acidosis. Circ. Res. 49:307-316.

3. Rouslin, W., and J. L. Erickson. 1986. Factors affecting loss of mitochondrial function in autolyzing cardiac muscle. J. Mol. Cell. Cardiol. 18:1187-1195.

4. Rouslin, W. 1983. Protonic inhibition of the mitochondrial oligomycin-sensitive adenosine 5'-triphosphatase in ischemic and autolyzing cardiac muscle. J. Biol. Chem. 258:9657-9661.

5. Pentilla, A., and B. F. Trump. 1974. Extracellular acidosis protects Ehrlich tumor cells and rat renal cortex against anoxic injury. Science (Wash. DC). 185:272-278.
6. Bonventre, J. V., and J. C. Cheung. 1985. Effects of metabolic acidosis on viability of cells exposed to anoxia. Am. J. Physiol. 249:C149-C159.

7. Gores, G. J., A.-L. Nieminen, T. L. Dawson, B. Herman, and J. J. Lemasters. 1988. Extracellular acidosis delays the onset of cell death in ATP-depleted hepatocytes. Am. J. Physiol. 255:C315-322.

8. Andersson, B. S., T. K. Aw, and D. P. Jones. 1987. Mitochondrial transmembrane potential and $\mathrm{pH}$ gradients during anoxia. Am. J. Physiol. 252:C349-C355.

9. DiGuiseppi, J., R. Inman, A. Ishihara, K. Jacobson, and B. Herman. 1985. Applications of digitized fluorescence microscopy to problems in cell biology. BioTechniques. 3:349-403.

10. Bright, G. R., G. W. Fisher, J. Rogowska, and D. L. Taylor. 1987. Fluorescence ratio imaging microscopy: temporal and spatial measurements of cytoplasmic pH. J. Cell Biol. 104:1019-1033.

11. Lemasters, J. J., J. DiGuiseppi, A.-L. Nieminen, and B. Herman. 1987. Blebbing, free $\mathrm{Ca}^{++}$, and mitochondrial membrane potential preceding cell death in hepatocytes. Nature (Lond.). 325:78-81.

12. Herman, B., A.-L. Nieminen, G. J. Gores, and J. J. Lemasters. 1988. Irreversible injury in anoxic hepatocytes precipitated by an abrupt increase in plasma membrane permeability. FASEB (Fed. Am. Soc. Exp. Biol.) J. 2:146-151.

13. Bissel, D. M., D. M. Arenson, J. J. Maher, and F. J. Roll. 1987. Support of cultured hepatocytes by a laminin-rich gel. J. Clin. Invest. 79:801-812.

14. Good, N. E., G. D. Winget, W. Winter, T. N. Conally, S. Izawa, and R. M. M. Singh. 1966. Hydrogen ion buffers for biological research. Biochemistry. 5:467-477.

15. Rink, T. J., R. Y. Tsien, and T. Pozzan. 1982. Cytoplasmic pH and free $\mathrm{Mg}^{++}$in lymphocytes. J. Cell Biol. 95:189-196.

16. Ohkuma, S., and B. Poole. 1978. Fluorescein probe measurements of the intralysosomal $\mathrm{pH}$ in living cells and the pertubations of pH by various agents. Proc. Natl. Acad. Sci. USA. 75:3372-3331.

17. Lake, J. R., R. W. Van Dyke, and B. F. Scharschmidt. 1987. Acidic vesicles in cultured rat hepatocytes. Gastroenterology. 92:1251-1291.

18. Paradiso, A. M., P. A. Negulescu, and T. E. Machen. 1986. $\mathrm{Na}^{+}-\mathrm{H}^{+}$and $\mathrm{Cl}^{-}-\mathrm{OH}^{-}\left(\mathrm{HCO}_{3}^{-}\right)$exchange in gastric glands. Am. J. Physiol. 250:G524-G534.

19. Andersson, B. S., and D. P. Jones. 1985. Use of fractionation to determine mitochondrial transmembrane ion distribution in cells during anoxia. Anal. Biochem. 146:164-172.

20. Roe, M. W., J. J. Lemasters, and B. Herman. 1987. An assessment of the use of Fura-2 for the determination of intracellular calcium concentration. Fed. Proc. 46:2277a. (Abstr.)

21. Davis, M. H., R. A. Altschuld, D. W. Jung, and G. P. Brierley. 1987. Estimation of intramitochondrial $\mathrm{pCa}$ and $\mathrm{pH}$ by Fura- 2 and 2,7,biscarboxyethyl-5(6)-carboxyfluorescein (BCECF) fluorescence. Biochem. Biophys. Res. Commun. 149:40-45.

22. Steinberg, S. F., J. P. Bilezikan, and Q. Al-Awqati. 1987. Fura-2 fluorescence is localized to mitochondria in endothelial cells. Am. J. Physiol. 253:C744-C747.

23. Malgaroli, A., D. Milani, J. Meldolesi, and T. Pozzan. 1987. Fura-2 measurements of cytosolic free $\mathrm{Ca}^{++}$in monolayers and suspensions of various types of animal cells. J. Cell Biol. 105:2145-2155.

24. Zuurendonk, P. F., and J. M. Tager. 1974. Rapid separation of particulate components and soluble cytoplasm of isolated rat-liver cells. Biochim. Biophys. Acta. 333:393-399.

25. Kashiwagura, T., C. J. Deutsch, J. Taylor, M. Erecinska, and D. F. Wilson. 1984. Dependence of gluconeogenesis, urea synthesis, and energy metabolism of hepatocytes on intracellular pH. J. Biol. Chem. 259:237-243.

26. Starlinger, M., A. M. Paradiso, and T. E. Machen. 1987. Steady state regulation of intracellular $\mathrm{pH}$ in isolated rabbit gastric glands. Gastroentrology. 92:957-965.

27. Brandford, C. B., M. S. Aronow, T. A. Brock, E. Gragoe, M. A. Gimbrone, Jr., and R. W. Alexander. 1987. Angiotensin II-stimulated 
$\mathrm{Na}^{+} / \mathrm{H}^{+}$exchange in cultured vascular smooth muscle cells. J. Biol. Chem. 262:5057-5064.

28. Lemasters, J. J., C. J. Stemkowski, S. Ji, and R. G. Thurman. 1983. Cell surface changes and enzyme release during hypoxia and reoxygenation in the isolated, perfused rat liver. J. Cell Biol. 97:778-786.

29. Anundi, I., J. King, D. A. Owen, H. Schneider, J. J. Lemasters, and R. G. Thurman. 1987. Fructose prevents hypoxic cell death in liver. Am. J. Physiol. 253:G390-G396.

30. Garlick, P. B., G. K. Radda, and P. J. Seeley. 1979. Studies of acidosis in the ischemic heart by phosphorous nuclear magnetic resonance. Biochem. J. 184:547-554.

31. Sehr, P. A., P. J. Bore, J. Papatheofanis, and G. K. Radda. 1979. Non-destructive measurements of metablites and tissue $\mathrm{pH}$ in the kidney by ${ }^{31} \mathrm{P}$ nuclear magnetic resonance. Br. J. Pathol. 60:632641.

32. Walsh, P. J. 1986. Ionic requirements for intracellular $\mathrm{pH}$ regulation in rainbow trout hepatocytes. Am. J. Physiol. 250:R24-R29.

33. Henderson, R. M., J. Graf, and J. L. Boyer. 1986. Na-H exchange regulates intracellular $\mathrm{pH}$ in isolated rat hepatocyte couplets. Am. J. Physiol. 252:G109-G113.

34. Renner, E. L., J. R. Lake, and B. F. Scharschmidt. 1987. Hepatocytes express a mechanism for $\mathrm{Na}^{+} / \mathrm{HCO}_{3}^{-}$transport unrelated to $\mathrm{Na}^{+} / \mathrm{H}^{+}$or $\mathrm{Cl}^{-} / \mathrm{HCO}_{3}^{-}$exchange. Clin. Res. 35:412a. (Abstr.)
35. Hochachka, P. W., and T. P. Mommsen. 1983. Protons and anaerobiosis. Science (Wash. DC). 219:1391-1397.

36. Webb, J. L. 1966. Enzyme and Metabolic Inhibitors. Vol 3. Academic Press, Inc., New York. 1028 pp.

37. Ross, A., and W. F. Boron. 1981. Intracellular pH. Physiol. Rev. 61:296-434.

38. Aw, T. Y., B. S. Andersson, and D. P. Jones. 1987. Mitochondrial transmembrane ion distribution during anoxia. Am. J. Physiol. 252:C356-C361.

39. Aw, T. Y., B. S. Andersson, and D. P. Jones. Suppression of mitochondrial respiratory function after short-term anoxia. Am. $J$. Physiol. 252:C362-C368.

40. Farber, J. L., K. R. Chien, and S. Mittnacht. 1981. The pathogenesis of irreversible cell injury in ischemia. Am. J. Pathol. 102:171178.

41. Nicotera, P., P. Hartzell, C. Baldi, S.-A. Svensson, G. Bellomo, and S. Orrenius. 1986. Cystamine induces toxicity in hepatocytes through the elevation of cytosolic $\mathrm{Ca}^{++}$and the stimulation of a nonlysosomal proteolytic system. J. Biol. Chem. 261:14628-14635.

42. Gores, G. J., A.-L. Nieminen, B. Herman, and J. J. Lemasters. 1987. Intracellular acidosis protects against cell death in isolated rat hepatocytes during 'chemical hypoxia'. Hepatology (Baltimore). 7:1027. (Abstr.) 